\title{
Penyelesaian Sengketa Laut Antara Indonesia dan Malaysia di Wilayah Selat Malaka Menurut Hukum Laut Internasional
}

\author{
Maulidya Yuseini \\ Universitas Negeri Surabaya, Indonesia \\ maulidyayuseini98@gmail.com
}

\section{Dian Rachmawati}

Universitas Negeri Surabaya, Indonesia

dirar8025@gmail.com

\section{Fransiska Yuardini}

Universitas Negeri Surabaya, Indonesia

yuardinidini@gmail.com

\author{
Hafidh Lukmam Syaifuddin \\ Universitas Negeri Surabaya, Indonesia \\ hafidhls18@gmai.com
}

\begin{abstract}
Dispute settlement between Indonesia and Malaysia in the Malacca Strait Region started with the unilateral claims of both countries. The prevailing these unilateral claims resulted in the area of Exclusive Economic Zone in the Malacca Strait to overlap. UNCLOS 1982 is the existing International Law of the Sea and both countries ratified to this Convention. The purpose of this article is to find out how to resolve sea border disputes between Indonesia and Malaysia in the Malacca Strait Region under the Law of the International Sea. This article is also aimed to provide a narrative to the factors underlying the existing maritime border dispute.
\end{abstract}

KEYWORDS: Disputes settlement, Malacca Strait, Overlapping.

Copyright $\odot 2018$ by Author(s)

This work is licensed under a Creative Commons Attribution-ShareAlike 4.0 International License. All writings published in this journal are personal views of the authors and do not represent the views of this journal and the author's affiliated institutions.

\section{HOW TO CITE:}

Yuseini, Maulidya, Dian Rachmawati, Fransiska Yuardini \& Hafidh Lukman Syaifuddin. "Penyelesaian Sengketa Laut antara Indonesia dan Malaysia di Wilayah Selat Malaka Menurut Hukum Laut Internasional" (2018) 5:3 Lentera Hukum 483-492.

Submitted: May 23, 2018 Revised: June 04, 2018 Accepted: December 31, 2018 


\section{PENDAHULUAN}

Negara Kesatuan Republik Indonesia merupakan negara kepulauan yang memiliki banyak kekayaan alam. Kekayaan alam yang dimiliki oleh Indonesia tidak hanya terdapat di daratan, wilayah perairan pun juga memiliki banyak kekayaan alam diantaranya adalah terumbu karang, ikan, dan lain sebagainya. Adapun luas wilayah perairan NKRI mencapai $96.079,15 \mathrm{~km}$ dengan garis patai $81.000 \mathrm{~km} .{ }^{1}$

Letak Indonesia berbatasan dengan negara-negara lain, baik secara berhadapan maupun secara berdampingan, baik berbatasan dengan wilayah darat maupun wilayah laut. Perbatasan pada wilayah perairan dapat meliputi wilayah laut teritorial, zona tambahan maupun zona ekonomi eksklusif. Negara yang berbatasan dengan Indonesia salah satunya adalah Malaysia. Perbatasan antara wilayah Indonesia dengan wilayah Malaysia berdampingan dengan Pulau Kalimantan, sedangkan yang berhadapan dipisahkan dengan Selat Malaka.

Pada tanggal 17 Oktober 1969 negara Indonesia dan Malaysia melakukan perjanjian untuk menentukan batas landas kontinen antara kedua negara tersebut. Perjanjian ini menghasilkan putusan persetujuan antara pemerintah Republik Indonesia dan Pemerintah Malaysia tentang penetapan garis batas landas kontinen antara kedua negara yang telah ditandatangani oleh delegasi-delegasi pemerintah Republik Indonesia dan Pemerintah Malaysia di Kuala Lumpur. ${ }^{2}$ Perjanjian ini, ditandatangani pada tanggal 27 Oktober 1969. Perjanjian ini diratifikasi oleh Indonesia dengan dikeluarkannya Keputusan Presiden Republik Indonesia Nomor 89 Tahun 1969.

Landas Kontinen merupakan dasar laut dan tanah di bawahnya dari daerah di bawah permukaan laut yang terletak di luar laut teritorialnya sepanjang kelanjutan alamiah wilayah daratannya hingga pinggiran luar tepi kontinen atau hingga suatu jarak 200 (dua ratus) mil laut dari garis pangkal darimana lebar laut teritorial, dalam hal pinggiran luar tepi kontinen tidak mencapai jarak tersebut. ${ }^{3}$ Keberadaan landas kontinen ini memberikan hak-hak berdaulat untuk negara pantai yang wilayahnya meliputi landas kontinen tersebut. Hak berdaulat tersebut antara lain untuk mengeksploirasi dan mengeksploitasi sumber kekayaan alam di landas kontinen (Pasal 77 UNCLOS ayat 1 ).

Tiga belas tahun setelah adanya perjanjian antara Indonesia dengan Malaysia dilaksanakan tepatnya pada tahun 1982, Perserikatan Bangsa-Bangsa (PBB) melaksanakan Konvensi Hukum Laut di Janewa. Konvensi ini diadakan karena kemajuan yang semakin pesat dalam bidang teknologi kelautan, seperti teknologi penambangan dasar laut dan tanah di bawahnya yang sudah menjangkau pada jarak dan kedalaman yang sangat jauh, dan masih banyak yang lainnya. Selain itu, Negara-

\footnotetext{
Ridwan Lasabuda, Pembangunan Wilayah Pesisir dan Lautan Dalam Perspektif Negara Kepulauan Republik Indonesia, Jurnal Ilmiah Platax Vol.1-2 Januari 2013, diakses dari https://ejournal.unsrat.ac.id/index.php/platax/article/download/1251/1019, pada tanggal 15 April 2018 Pukul 12.10 WIB, hlm.3

2 Siahaan dan Suhendi, Hukum Laut Nasional (Himpunan Peraturan Perundang-Undangan Kemaritiman), (Jakarta: Penerbit Djambatan, 1989), hlm. 259.

3 Konvensi Perserikatan Bangsa-Bangsa (UNCLOS) 1982 Pasal 76 Ayat (l).
} 
negara di dunia saat itu, secara pribadi maupun bersama mulai memperkenalkan pranata hukum laut yang baru, seperti zona ekonomi ekslusif, zona ekonomi, zona perikanan, dan berbagai klaim lainnya. Keadaan tersebut membuat Negara-negara di dunia berlomba-lomba dalam menguasai lautan serta mengeksploitasi sumber daya alamnya. ${ }^{4}$

Klaim-klaim sepihak yang dilakukan oleh negara-negara dunia ini disebabkan karena kurang jelasnya hukum laut internasional yang mengatur saat itu. Hukum laut tersebut adalah Konvensi Hukum Laut Perserikatan Bangsa-Bangsa Tahun 1958 dan 1960. Adanya permasalahan dan ketidakpastian mengenai hukum laut tersebut menjadi dasar diselenggarakannya Konvensi Perserikatan Bangsa-Bangsa ketiga. Hasil dari adanya konvensi ini adalah lahirnya UNCLOS (United Nations Convention On The Law of The Sea) 1982 yang ditandatangani di Montego Bay, Jamaika, pada tanggal 10 Desember 1982. Pada Konvensi Perserikatan Bangsa-Bangsa ketiga ini, kemudian muncul wilayah perairan baru yaitu Zona Ekonomi Eksklusif (ZEE).

Sebagai salah satu anggota Perserikatan Bangsa-Bangsa, Indonesia kemudian meratifikasi UNCLOS 1982 dalam Undang-Undang Republik Indonesia Nomor 17 Tahun 1985 Tentang Pengesahan United Nations Convention On The Law of The Sea (Konvensi Perserikatan Bangsa-Bangsa Tentang Hukum Laut). Dengan diratifikasinya UNCLOS 1982 oleh Indonesia, maka Indonesia menyatakan tunduk pada peraturan-peraturan yang termuat di dalam UNCLOS 1982. Sama halnya dengan Indonesia, Malaysia sebagai salah satu anggota PBB juga turut meratifikasi UNCLOS 1982 Pada tanggal 14 Oktober 1996. Diratifikasinya UNCLOS ini membuat Malaysia pun tunduk pada ketentuanketentuan UNCLOS 1982.

Tahun 2011, terjadi sebuah insiden di Selat Malaka. Insiden tersebut melibatkan dua negara yaitu Indonesia dan Malaysia. Kronologi insiden ini diawali dengan adanya dua kapal berbendera Malaysia yang menangkap ikan di Wilayah Zona Ekonomi Eksklusif Indonesia (ZEE) di wilayah Selat Malaka. Kedua kapal tersebut kemudian tertangkap oleh Kapal Pengawas Hiu 001 milik Dirjen Pengawasan Sumber Daya Kelautan dan Perikanan Kementerian Kelautan Perikanan pada 7 April 2011. Kapal yang ditangkap Antara lain KM. KF 5325 GT 75, 80 dengan nahkoda berinisial KLA, dan kapal KM. KF 5195 GT 63, 80 yang dinahkodai NHOI. Kedua kapal ini ditangkap karena tidak memiliki SIUP (Surat Izin Usaha Perikanan) dan SIPI (Surat Izin Penangkapan Ikan) dari Pemerintah Republik Indonesia. Keduanya juga menggunakan alat penangkap ikan terlarang, yaitu Trawl. Setelah tertangkapnya dua kapal tersebut, kemudian digiring ke Pelabuhan Belawan. ${ }^{5}$

Penggiringan kedua kapal ini tidak berlangsung lancar, di tengah perjalanan terdapat tiga helikopter Malaysia yang menghalangi proses penangkapan tersebut. Petugas dalam helikopter itu, meminta Kapal Pengawas Hiu 001 untuk melepaskan dua

4 I Wayan Phartiana, Hukum Laut Internasional dan Hukum Laut Indonesia, (Bandung: Penerbit Yrama Widya, 2014), hlm. 18-19.

5 Suryanto, Penangkapan Kapal Malaysia Karena Langgar Batas (Selasa 12 April 2011), diakses dari https://m.antaranews.com/berita/253839/penangkapan-kapal-malaysia-karena-langgar-batas, tanggal 18 April 2018 pukul 17.05 WIB. 
kapal yang berbendera Malaysia, karena kedua kapal tersebut dianggap menangkap ikan di wilayah ZEE milik Malaysia. Permasalahan ini kemudian menjadi awal permasalahan perbatasan ZEE di wilayah Perairan Selat Malaka Antara Indonesia dengan Malaysia, sebab belum ada pengaturan yang disepakati oleh kedua belah pihak. ${ }^{6}$

Perbatasan ZEE (Zona Ekonomi Eksklusif) merupakan suatu daerah di luar dan berdampingan dengan laut teritorial, yang tunduk pada rezim hukum khusus yang ditetapkan dalam Bab ini berdasarkan mana hak-hak dan yurisdiksi negara pantai dan hak-hak serta kekebalan-kekebalan negara lain, diatur oleh ketentuan-ketentuan yang relevan Konvensi ini. ${ }^{7}$ Dalam pengukuran lebar zona ekonomi eksklusif oleh negara pantai ini adalah 200 mil laut yang dilakukan dari garis pangkal dari mana laut teritorial itu diukur dan tidak boleh melebihi dari 200 mil yang telah ditentukan. Dengan adanya penentuan ZEE pada sebuah negara pantai, memunculkan hak-hak berdaulat dan yurisdiksi dari sebuah negara pantai. Hak-hak berdaulat yang dimiliki oleh suatu negara pantai antara lain, hak dalam keperluan eksplorasi dan eksploitasi, konservasi, pengelolaan sumber daya alam hayati dan non hayati. Sedangkan yurisdiksi dari suatu negara pantai melakukan pembuatan dan pemakaian pulau buatan, instalansi, bangunan, untuk kepentingan penelitian ilmiah kelautan, serta untuk perlindungan dan pelestarian lingkungan laut.

Seperti yang dipaparkan pada penjelasan di atas tentang penangkapan dua buah kapal berbendara negara Malaysia, menyebutkan bahwa wilayah dimana Malaysia mengambil ikan merupakan wilayah ZEE mereka, padahal pada wilayah ZEE tersebut merupakan salah satu bagian wilayah ZEE milik Indonesia. Maka dari tragedi kapal di atas dan klaim masing-masing dari dua negara tersebut menyebabkan sengketa laut Indonesia dan Malaysia di Selat Malaka.

Klaim-klaim yang dilakukan oleh dua negara ini tentunya tidak sembarangan, karena dua negara tersebut melakukan klaim berdasarkan pada sebuah perjanjian dan ketentuan khusus. Pada Malaysia melakukan klaim berdasarkan pada perjanjian dengan Indonesia tahun 1969 yang pada saat itu menetapkan mengenai landas kontinen kedua negara juga sebagai garis ZEE. Sedangkan pada klaim Indonesia sendiri pada wilayah ZEE, Indonesia tidak berdasarkan pada perjanjian seperti yang dilakukan Malaysia, melainkan Indonesia menggunakan atas dasar Konvensi Hukum Laut PBB 1982 dengan menggunakan garis tengah (median line) antara Indonesia (Sumatra) dan semenanjung Malaysia sebagai garis batas ZEE. Indonesia pun sudah dengan tegas menunjukkan klaimnya dengan menerbitkan Peraturan Menteri (Permen) Kelautan

6 Kiki Natalia, Penyelesaian Permasalahan Batas Wilayah Antara Indonesia dan Malaysia Ditinjau dari UNCLOS 1982, Calyptra: Jurnal Ilmiah Mahasiswa Universitas Surabaya Vol. 2 No. 2 2013, Diakses dari http://download.portalgaruda.org/article.php?article=13425l\&val=5636, pada tanggal 15 April 2018 pukul 13.20 WIB.

Konvensi Perserikatan Bangsa-Bangsa (UNCLOS) 1982 Pasal 35 ayat (1). 
dan Perikanan Nomor 1 Tahun 2009 tentang Wilayah Pengelolaan Perikanan (WPP). ${ }^{8}$ Sehingga dari perbedaan klaim oleh kedua negara ini mengakibatkan munculnya sengketa kelautan Indonesia dan Malaysia yang berupa overlapping claim area (kawasan tumpang tindih). Klaim-klaim ini juga yang menjadi faktor penyebab adanya sengketa perbatasan Zona Ekonomi Eksklusif di wilayah Selat Malaka antara Indonesia dengan Malaysia.

Tumpang tindih atau overlapping berfokus pada airnya saja, tidak termasuk dasar laut, maka yang menjadi persolan disini adalah ikannya, bukan minyak gas dan bumi. Sehingga dapat dibenarkan apabila Indonesia melakukan tindakan penangkapan kapal milik Malaysia, karena pada saat itu Malaysia memasuki wilayah tumpang tindih milik Indonesia, sehingga dapat dikatakan bahwa Malaysia telah melakukan pelanggaran atas perbuatannya. Selain itu tumpang tindih yang terjadi antara Indonesia dan Malaysia juga diakibatkan karena kedua negara merupakan negara yang berhadapan dan berdampingan.

\section{PENYELESAIAN SENGKETA PERBATASAN LAUT ANTARA INDONESIA DAN MALAYSIA DI WILAYAH SELAT MALAKA}

Indonesia merupakan negara kepulauan yang di wilayah perairan negara Indonesia banyak terdapat selat. Salah satu selat yang terkenal yaitu Selat Malaka yang terletak diantara wilayah Indonesia, Malaysia dan Singapura. Selat Malaka ini merupakan sebuah jalur perdagangan dunia selain dari terusan Suez dan Terusan Panama. Konsekuensi dari hal tersebut membuat wilayah yang startegis sehingga ramai oleh aktivitas pedagangan dan pelayaran dari berbagai negara dipenjuru dunia. Hal tersebut yang membuat selat ini memiliki nilai ekonomi yang tinggi bagi negara yang berada di sekitar Selat Malaka. Dampak dari nilai ekonomi yang tinggi membuat wilayah tersebut rawan terjadi konflik. Seperti halnya permasalahan sengketa perbatasan laut antara Indonesia dengan Malaysia di wilayah Selat Malaka.

Sengketa laut tumpang tindih yang terjadi pada Zona Ekonomi Eksklusif antara Indonesia dengan Malaysia dapat diselesaikan dengan cara damai. Kedua negara tersebut merupakan negara tetangga yang yang seharusnya memiliki hubungan kerjasama yang baik, akan tetapi belum ada kesepakatan mengenai batas ZEE antara negara Indonesia dan Malaysia di Selat Malaka menjadi faktor sengketa yang harus segera diselesaikan. Masing-masing negara memiliki klaim sendiri mengenai garis batas Zona Ekonomi Eksklusif di wilayah tersebut. ${ }^{9}$

Sengketa antara Indonesia dengan Malaysia ini dapat diselesaikan menggunakan UNCLOS 1982 (United Nation Convention on the Law Of Sea 1982) atau biasa disebut Konvensi Hukum Laut Internasional. Indonesia dan Malaysia telah menjadi anggota

8 I Made Arsana, Insiden Selat Malaka, 13 April 2011, diakses dari https://m.detik.com/news/kolom/1615124/insiden-selat-malaka, pada tanggal 18 April 2018 Pukul 18.08 WIB.

9 Kiki Natalia, supra note 6, hlm. 5. 
Perserikatan Bangsa-Bangsa yang telah meratifikasi Konvensi Hukum Laut Internasional tersebut. Hal ini dapat dibuktikan dengan dikeluarkannya UndangUndang Nomor 17 Tahun 1985 tentang pengesahan UNCLOS 1982 oleh Pemerintah Republik Indonesia, sedangkan Malaysia telah meratifikasi UNCLOS pada tanggal 14 Oktober 1996 (United Nations,2009). Adanya peratifikasian Konvensi Hukum Laut Internasional oleh kedua negara yang bersengketa, menjadi faktor mengapa UNCLOS menjadi acuan dasar penyelesaian sengketa tumpang tindih di Selat Malaka ini. ${ }^{10}$

Indonesia dengan Malaysia saling mempermasalahkan mengenai lebar Zona Ekonomi Eksklusif di Selat Malaka. Kedua negara tersebut hanya membuat perjanjian mengenai batas landas kontinen pada tanggal 27 Oktober 1969. Pengaturan Landas kontinen dan Zona Ekonomi Eksklusif itu tidak dapat disamakan, karena masingmasing wilayah tersebut memiliki perbedaan dalam sistem pengaturannya. Letak Indonesia yang berhadapan dan berdampingan dengan Malaysia membuat Pasal 15 UNCLOS 1982 menjadi pengaturan yang tepat untuk menentukan perbatasan wilayah Zona Ekonomi Eksklusif.

Pasal 15 UNCLOS mengatur tentang penetapan garis batas laut teritorial antara negara-negara pantainya berhadapan atau berdampingan yang pada Ayat (1) berbunyi, "Dalam hal pantai dua Negara yang letaknya berhadapan atau berdampingan satu sama lain, tidak satupun diantara berhak, kecuali ada persetujuan yang sebaliknya antara mereka, untuk menetapkan batas laut teritorialnya melebihi garis tengah yang titiktitiknya sama jaraknya dari titik-titik terdekat pada garis-garis pangkal dari mana lebar laut teritorial masing-masing Negara diukur." Sedangkan pada ayat (2) yang berbunyi, "Tetapi ketentuan di atas tidak berlaku, apabila terdapat alasan hak historis atau keadaan khusus lain yang menyebabkan perlunya menetapkan batas laut teritorial antara kedua Negara menurut suatau cara yang berlainan dengan ketentuan di atas."

Pada intinya dalam Pasal 15 UNCLOS 1982 menjelaskan bahwa lebar laut teritorialnya masing-masing negara dapat ditetapkan berdasarkan garis tengah kecuali terdapat alasan historis atau keadaan khusus lainnya. Di wilayah ZEE inilah Indonesia dan Malaysia mempermasalahkan mengenai penentuan batas wilayah, karena lebar wilayah terutama di Selat Malaka antara kedua negara tersebut yang letaknya saling berhadapan atau berdampingan, lebar dari ZEE kurang dari 400 mil. ${ }^{11}$ Oleh sebab itu, Indonesia mendesak Malaysia untuk merundingkan perjanjian mengenai perbatasan ZEE karena Indonesia dirugikan secara ekonomi, politik dan pertahanan keamanan di wilayah tersebut.

Malaysia selama ini menganggap perjanjian batas kontinen dengan Indonesia pada tahun 1969 ( yang mana telah menyepakati 25 titik yang terdiri dari 10 koordinat di selat Malaka dan 15 titik koordinat di Laut Cina Selatan serta sudah sesuai dengan ketentuan dalam konvensi PBB 1 tahun 1958) sekaligus sebagai perjanjian mengenai lebar ZEE yang mana hal tersebut telah melanggar ketentuan dan prinsip yang ada pada UNCLOS 1982, karena pengaturan mengenai ZEE (tepatnya pada pasal 55,56,57

$\begin{array}{ll}10 & \text { Ibid. } \\ & 11 \\ & \text { Ibid, 6-7. }\end{array}$ 
UNCLOS 1982) dengan batas kontinen (pasal 76 UNCLOS 1982) sangat berbeda, sehingga pernyataan Malaysia yang menyamakan bahwa perjanjian batas kontinen sama dengan perjanjian ZEE telah merugikan Indonesia secara ekonomi, politik dan pertahanan keamanan. ${ }^{12}$

Penangkapan yang dilakukan Indonesia terhadap 2 kapal milik warga negara Malaysia di wilayah ZEE Indonesia menimbulkan sebuah protes dari Malaysia yang mana wilayah ZEE tersebut masih batas dari wilayah Malaysia yang mana hal ini menunjukkan bahwa lebar dari ZEE kedua negara belum jelas. Jika mengacu pada pasal 74 UNCLOS 1982, penetapan batas ZEE negara yang pantainya berhadapan atau berdampingan harus berdasarkan persetujuan atas dasar hukum internasional sebagaimana sengketa yang dihadapi oleh Indonesia dengan Malaysia untuk mencapai pemecahan masalah yang adil. UNCLOS 1982 memberikan pengaturan bagi anggotanya dalam menyelesaikan suatu sengketa hukum laut, tepatnya pada pasal 279 UNCLOS 1982 yang berbunyi, "negara-negara peserta harus menyelesaikan setiap sengketa antara mereka perihal interpretasi atau penerapan konvensi ini dengan cara damai sesuai dengan Pasal 2 ayat 3 Piagam Perserikatan Bangsa-Bangsa dan, untuk tujuan ini, harus mencari penyelesaian dengan cara sebagaimana ditunjukkan dalam pasal 33 ayat 1 Piagam tersebut". Jadi berdasarkan bunyi pasal di atas dapat dikatakan bahwa setiap anggota UNCLOS 1982 wajib menyelesaikan sengketa internasional dengan cara damai.

Kawasan yang diakui oleh kedua belah pihak disebabkan karena adanya perbedaan klaim yang disebut kawasan tumpang tindih atau overlapping claim area. Meskipun dalam kasus ini belum ada kesepakatan, namun Kedua negara yaitu Indonesia dengan Malaysia masih menganggap kawasan tumpang tindih sebagai Zona Ekonomi Eksklusif mereka. Indonesia menetapkan klaim perbatasan ZEE dengan garis tengah berdasarkan ketentuan dalam UNCLOS, sedangkan Malaysia mengklaim perbatasan ZEE di Selat Malaka dengan perjanjian landas kontinen 1969.

Ada beberapa solusi yang dapat diterapkan dalam penyelesaian sengketa perbatasan ZEE di Selat Malaka antara lain: pertama, dalam menyelesaikan kasus antara Indonesia dan Malaysia ialah penetapan batas maritim. Kedua, Indonesia dan Malaysia sama-sama telah meratifikasi UNCLOS maka kedua negara harus mengacu pada UNCLOS dalam menyelesaikan proses sengketa perbedaan penetapan garis batas Zona Ekonomi Eksklusif. Ketiga, usulan Malaysia yang mempunyai niat menggunakan garis batas landas kontinen 1969 tidak dapat diterima karena pengaturan perbatasan landas kontinen dan ZEE memiliki ketentuan yang berbeda, sedangkan Usulan Indonesia yang menggunakan garis tengah sebagai garis batas ZEE di Selat Malaka nampaknya lebih bisa diterima. Keempat, apabila usulan Indonesia diterima berarti garis batas landas kontinen berbeda dengan garis batas Zona Ekonomi Eksklusif akan ada kawasan di Selat Malaka dasar lautnya jadi milik Malaysia tetapi air di atasnya milik Indonesia. Kelima, menyepakati suatu konsensus penanganan kejadian yang sama dalam kawasan tumpang tindih sehingga petugas yang berada di lapangan bertindak sesuai dengan konsensus yang sudah dicapai oleh pihak yang lebih tinggi. Keenam,

12 Ibid. 
apabila sebelum garis batas final dicapai kawasan tumpang tindih dibebaskan dari segala aktivitas dan memperhatikan dampak bagi para nelayan yang hidupnya bergantung pada sumberdaya laut di Selat Malaka. ${ }^{13}$

Solusi yang telah disebutkan di atas dapat menjadi sebuah pertimbangan bagi kedua pihak dalam melakukan penyelesaian sengketa. Tidak adanya kejelasan perbatasan wilayah ZEE di Selat Malaka, membuat nelayan kesulitan dalam menentukan wilayah penangkapan ikan sehingga merugikan pihak nelayan. Dengan diberikan beberapa pendapat di atas diharapkan dapat mempermudah penyelesaian sengketa antara Indonesia dengan Malaysia.

Adapun jalur penyelesaian untuk sengketa perbatasan laut antara Indonesia dengan Malaysia di wilayah Selat Malaka antara lain: Yang pertama, batas maritim bisa diselesaikan dengan cara negosiasi, mediasi, arbitrasi dan pengajuan ke lembaga peradilan internasional seperti Mahkamah Internasional (ICJ) dan ITLOS. Yang kedua, sejauh ini Indonesia dan Malaysia masih menempuh cara negosiasi bilateral, kelebihan dari negosiasi ini yaitu kasus sepenuhnya berada dalam kendali para pihak yang bersengketa, berbeda jika diajukan ke pengadilan internasional. Yang ketiga, semua pihak harus memahami sifat negosiasi bahwa tidak ada satu pihakpun akan mendapatkan semua yang diinginkan, dengan demikian semua pihak akan mendapat bagian walapun lebih sedikit karena itulah intinya dari negosiasi. Dibandingkan dengan menggunakan jalur pengadilan internasional, yang dapat dimungkinkan satu pihak tidak mendapatkan hasil yang memuaskan sementara pihak lain mendapatkan semua yang diinginkannya. Jadi, nantinya apapun jalur yang akan ditempuh masingmasing negara untuk menyelesaikan sengketa tersebut pastinya tetap saling menhormati serta menghargai dan juga menjunjung perdamaian sehingga antar kedua negara bisa menyelesaikan sengketa perbatasan laut sebagai dua bangsa yang saling menghargai dan menjunjung perdamaian, apapun jalur yang ditempuh, Indonesia dan Malaysia akan menyelesaikan persoalan ini dengan cara damai. ${ }^{14}$

\section{KESIMPULAN}

Indonesia dan Malaysia memiliki hak atas ZEE di Selat Malaka. Hal ini dikarenakan lebar ZEE kedua negara kurang dari 400 mil sebagaimana dijelaskan dalam pasal 56 UNCLOS 1982 yang pada intinya kedua negara baik Indonesia maupun Malaysia memiliki hak berdaulat di wilayah tersebut baik untuk keperluan eksplorasi dan eksploitasi, konservasi dan pengelolaan sumber daya alam baik hayati dan non hayati. Penyelesaian sengketa antara Indonesia dengan Malaysia dapat diselesaikan sesuai dengan apa yang diinginkan oleh kedua negara, baik menempuh jalur litigasi maupun non litigasi sebagaimana yang diatur dalam pasal 280 UNCLOS 1982. Dan penyelesaian tersebut harus diselesaikan dengan cara damai sebagaimana yang diatur dalam pasal 279 UNCLOS 1982.

13 I Made Arsana, supra note 8.
Ibid. 
Saran dari kami, penyelesaian sengketa mengenai lebar ZEE dapat diselesaikan dengan cara negosiasi, mediasi, arbitrasi dan pengajuan ke lembaga peradilan internasional seperti Mahkamah Internasional (ICJ) dan ITLOS. Yang kedua dengan cara negosiasi bilateral, karena kelebihan dari negosiasi ini yaitu kasus sepenuhnya berada dalam kendali para pihak yang bersengketa, berbeda jika diajukan ke pengadilan internasional, yang memiliki kemungkinan satu pihak tidak mendapatkan hasil yang baik sementara pihak lain mendapatkan semua yang diinginkannya. Jadi, nantinya apapun jalur yang akan ditempuh masing-masing negara untuk menyelesaikan sengketa tersebut pastinya tetap saling menghormati serta menghargai dan juga menjunjung perdamaian sehingga antar kedua negara bisa menyelesaikan sengketa perbatasan laut sebagai dua bangsa yang saling menghargai dan menjunjung perdamaian, apapun jalur yang ditempuh, Indonesia dan Malaysia akan menyelesaikan persoalan ini dengan cara damai.

\section{DAFTAR PUSTAKA}

Arsana, I Made Andi. 2011. Insiden Selat Malaka. diakses dari https:/m.detik.com/news/kolom/1615124/insiden-selat-malaka. pada tanggal 18 April 2018 Pukul 18.08 WIB

Bangun, Budi Hermawan. 2017. Konsepsi dan Pengelolaan Wilayah Perbatasan Negara: Perspektif Hukum Internasional. Tanjungpura Law Journal, Vol. 1, Issue 1, January 2017: 52-63.

Kusumo, Ayub Torry Satriyo dan Leksono, Handojo. 2013. Alternatif Penyelesaian Sengketa Wilayah Laut Indonesia-Malaysia. Yustisia Vol. 2 No. 1 Januari-April 2013.

Lasabuda, Ridwan. 2013. Pembangunan Wilayah Pesisir dan Lautan dalam Perspektif Negara Kepulauan Republik Indonesia. Jurnal Ilmiah Platax Vol. 1-2, Januari 2013.

Natalia, Kiky. 2013. Penyelesaian Permasalahan Batas Wilayah Antara Indonesia dan Malaysia Ditinjau dari UNCLOS 1982. Calyptra: Jurnal Ilmiah Mahasiswa Universitas Surabaya Vol. 2 No. 22013.

Palenewen, Rialindy Justitia. 2013. Eksistensi Garis Batas Landas Kontinen Antara Indonesia Dengan Malaysia Ditinjau Dari Hukum Laut Intenasional. Lex et Societatis, Vol. 1 No. 4 Agustus 2013.

Parthiana, I Wayan. 2014. Hukum Laut Internasional dan Hukum Laut Indonesia. Bandung: Penerbit Yrama Widya.

Siahaan dan Suhendi. 1989. Hukum Laut Nasional (Himpunan Peraturan Perundang-Undangan Kemaritiman). Jakarta: Penerbit Djambatan.

Purwaka, Tommy Hendra. 2014. Tinjauan Hukum Laut Terhadap Wilayah Negara Kesatuan Republik Indonesia. Mimbar Hukum Vol. 26, No. 3, Oktober 2014: 355-365.

Sodik, Dikdik Muhammad. 2014. Hukum Laut Internasional dan Pengaturannya di Indonesia (edisi revisi). Bandung: Refika Aditama.

Subagyo, P. Joko. 2005. Hukum Laut Indonesia. Jakarta: Rineka Cipta. 
492 | Penyelesaian Sengketa Laut Antara Indonesia dan Malaysia di Wilayah Selat Malaka Menurut Hukum Laut...

Suryanto. 2011. Penangkapan Kapal Malaysia Karena Langgar Batas. diakses dari https://m.antaranews.com/berita/253839/penangkapan-kapal-malaysia-karena-langgarbatas, tanggal 18 April 2018 pukul 17.05 WIB

Tirtamulia, Tjondro. 2011. Zona-Zona Laut UNCLOS. Surabaya: Brilian Internasional. 